\title{
A MODEL SCHOOL
}

By Propessor P. P. Claxton, head of the Department of Pedagogy in the University of Tennessee

The model country school, after all, is not so difficult a thing to realize if we consider a few principles of education which will give us an idea of what the country school should be like. We must remember that in all time it has been the purpose of education to prepare the pupils for the lives which they are to live. We must remember, also, that all education grows out of the life that the people really live. It is a selective process, it is a revising process. The law of the less of interest the less of growth, the rule of beginning where you are and going to where you must reach, hold in the country just as they do in the city.

The time was when we took probably one boy out of ten and one girl out of fifteen or twenty, or more, and we expected these people to be professional men, or ladies and gentlemen of leisure; they were to be lawyers and statesmen and orators and literary gentlemen; they were to be possible leaders, they were to have to do in some way with talk, and we taught them for that purpose very largely, and so we had a fixed course. But the day has come when we are undertaking to educate the children of all the people for all the walks of life. We are beginning to try the great experiment of bringing intelligence and intellectuality and heart and spirit to all industry, to all the life that all the people must live. We are trying to answer that great prayer that Jesus prayed for His disciplesnot to take them out of the world, but to make them a part of the world; that each boy and girl may do with less labor the work their parents did, and that each man shall walk away from his daily task a free man; that the man who turns the clod may himself be more than a clod and the man that beats the anvil may have a heart more sympathetic than his own iron.

All people must be prepared for two things. First, they must be prepared for life. That is the great thing in educational machinery, it must give culture, that enlargement, that giving of the mind, that giving of the soul and the heart to the task, that bringing of

\section{[245]}


each individuality into contact with the great human interests of the world. Without that, all life must be a failure. Whether the boy is to live in the country as a farmer, or in the city as a professional man, the one great profession of all men, and all women, is humanity. So every school, in the city or in the country, must remember to open its doors to humanity for the pupils in the schools, it must make of them men and women, it must bring them into contact with the great sources of inspiration, with the great literature, with the great heart of the world, with all that lifts up.

The second thing to be remembered is that all people must make a living. The day has come when people do not live in honor when they live by the labor of some one else. Every person must in some way either make his or her own support or contribute to the good of the world. I have come to believe that a good long step towards honest living is the ability to make an honest living, and that an honest life grows easily out of the ability to work in such a way that your work will contribute to your support and the support of those dependent on you. One must bear one's own burden and do something towards bearing the common burden. We will learn some day that that is the true solution of the negro problem in the South, when each negro has some ambition to make his own living and do something more; then other phases of the race problem will rapidly get out of the way.

With this in mind, what shall we do? The country school is for country children who know about country things, and who, if our civilization is to continue as it is in the South, must largely live in the country, though of course some of them will go to the city. For that reason the state will have to educate some of its own citizens in the country.

The country school should have a minimum of three acres of land. I think it ought to have more than that. I have to do with one where we have about twelve acres of land. There is a hill on which the schoolhouse is to be built, which slopes down to a pond. We are going to plant trees there and down at the pond we are going to plant water lilies. We are going to build a schoolhouse which will have six rooms about 24 by 36 feet, and in addition there will be a large assembly room, large enough to accommodate the, people who will come there to any entertainment for the people of the district. There will be halls and cloak rooms in addition. It will be 
built in an artistic way. The ceilings will be thirteen feet high, the rooms well lighted and well ventilated, and there will be water in it, pumped from a little spring down at the foot of a hill. It will be built of wood. I had a letter recently saying that it could be built of stone if we had another $\$ I, 500$; it is in a marble region; think of a marble schoolhouse!

There will be a house for the teacher. There ought to be teacherages in the country, as well as parsonages. The plans have been drawn for a house to cost about $\$ 1,75^{\circ}$; it would cost about $\$ 3,000$ in the city. It will be a good home for the teacher. To begin with, it will have the grounds around it laid out by our professor of horticulture in Tennessee. The principal of the school will be required to live in that house and keep it in such a way that the grounds and the house will be a model for the people about there. An orchard will be planted on the hill back of the schoolhouse, a strawberry bed will be made, if not for the sake of the fruit, at least for the sake of showing how to care for a vineyard and how to support it and how to pick off a few grapes so that the remainder will grow larger and be better than if all were allowed to remain on the vine. We shall attempt not to make any experiments, but to show what has been done in other places. We shall require the principal to see that it shall be demonstrated to the farmers what has been done by the most advanced knowledge in raising grapes in that section.

The course of study in a country school should be broad. I believe in the freest kind of election. All children should be taught to read, to write, to spell, something of language and something of culture from the human side. I suppose geography is in that list, the connection between the dead sciences and the live sciences if I may call them such for the moment, and history and literature. Through that course of study there will be a reading lesson every day. Children will be taught to read in a year or two, and then they will read for the sake of the matter. It will be the great literature of the world, that ought to be the common heritage of all the people-great because it takes hold of the human heritage of the heart. Then there will be a laboratory for chemistry and physics.

Some years ago I had the opportunity of studying the schools of Liverpool. I learned there the great lesson that little children 
twelve to fifteen years old may begin in a laboratory, with apparatus that costs very little, to learn the great fundamental principles of physics and chemistry. That knowledge one must have in modern life to understand the things about him. The laboratory is not for everybody, but certainly for those who go into the higher grades.

There will be a shop in this school where boys can learn to do with hammer and plane the things necessary on a farm, and the girls will be taught to cook and sew.

I think everybody believes now, except a very few people, that the school must take hold on life; that if the girls in the country must take hold of that which is provided by their fathers and brothers and husbands, and use a fractional part of it and sell what remains to the world and put the money in the bank, then there is the opportunity for education to serve our country people.

Next comes the question of the teacher. If the people of the South solve the question of the teacher, all other questions will be solved. The Germans say, "As is the teacher, so is his school." The Swedes go further and say, "The teacher is the school." If we had in our Southern country nothing but bright, thinking men and women for teachers, we would have everything all right. We shall try to get the proper kind of teachers in those schools. Why should all teachers have the same examination? Let us find a man who can teach horticulture, a woman who can teach cooking and sewing. It makes no difference if she doesn't know whąt is the longest river in the world-she is teaching sewing.

We want somebody who can teach vocal music. The most practical thing, in city or country, after reading and writing, is the power to sing. I can be reasonably happy if I cannot translate American money into Russian kopecks, but I could not be happy if I could not sing at churches and Sunday schools. We want some one to teach the children how to sing; and if she does not know percentage quite well but can teach singing, I should say we need her for that school. In other words, we need six teachers for that school, for from two hundred and fifty to three hundred children live in a mile and a half of that school, and it hurts no child to walk that far.

I understand the difficulty of making any new thing a success, but these things are not very difficult, and the scheme ought to succeed. 